\title{
PENDAPATAN NON-HALAL, ZAKAT, DEWAN PENGAWAS SYARIAH DAN REPUTASI PERBANKAN SYARIAH DI INDONESIA
}

\author{
Indria Puspitasari Lenap*, Nina Karina Karim, Elin Erlina Sasanti \\ Universitas Mataram, Indonesia \\ indrialenap@unram.ac.id,ninakarim@unram.ac.id, elleen7@yahoo.com \\ https://doi.org/10.46367/jas.v5i1.312
}

Received: Apr 07, 2021 Revised: May 31, 2021 Accepted: Jun 05, 2021 Published: Jun 28, 2021

\begin{abstract}
This study examines the influence of non-halal funds, zakat, and the number of Sharia Supervisory Board (SSB) on the reputation of Islamic banking in Indonesia. The sample is determined by the purposive sampling method and resulted in 7 banks or 35 observations from 2014 to 2018. The results showed that non-halal funds did not affect the reputation of Islamic banking. However, non-halal funds in the company's financial report notes show that Islamic banks, especially in Indonesia, have not fulfilled sharia regulations. The results also showed that zakat affects the reputation of Islamic banking. Zakat in Indonesia is greatly influenced by company size in terms of its assets. Zakat paid by Islamic banks in Indonesia is still low, and the gap for the welfare of the directors and employees of Islamic banks is a huge difference. Furthermore, this study indicated that the number of SSB affects the reputation of Islamic banking. Therefore, SSB has a significant role in compiling reports about sharia compliance. The ideal number of SSB is between 3 and 6 people.
\end{abstract}

Keywords: Reputation, Non-Halal Funds, Zakat, Sharia Supervisory Board.

\begin{abstract}
ABSTRAK
Penelitian ini bertujuan untuk menguji pengaruh pendapatan non-halal, zakat, jumlah Dewan Pengawas Syariah (DPS) terhadap reputasi perbankan syariah di Indonesia. Teknik pengambilan sampel menggunakan purposive sampling dengan jumlah sampel yang digunakan dalam penelitian ini yaitu 7 perusahaan atau 35 observasi dalam rentang tahun 2014-2018. Hasil penelitian menunjukkan bahwa pendapatan non-halal tidak berpengaruh terhadap reputasi perbankan syariah. Adanya pendapatan non-halal dalam catatan laporan keuangan perusahaan menunjukkan bahwa bank syariah khususnya di Indonesia belum sepenuhnya taat pada ketentuan syariah. Hasil penelitian juga menunjukkan bahwa zakat berpengaruh terhadap reputasi perbankan syariah. Zakat di Indonesia sangat dipengaruhi oleh seberapa besar ukuran perusahaan dalam hal ini aset yang dimiliki. Zakat yang dibayarkan oleh bank syariah di Indonesia masih rendah dan perbedaan kesejahteraan direktur dengan karyawan bank syariah masih besar. Selanjutnya, jumlah DPS berpengaruh terhadap reputasi perbankan syariah. DPS memiliki peran yang signifikan dalam menyusun laporan tentang tingkat kepatuhan syariah. Jumlah DPS yang ideal adalah antara 3 sampai dengan 6 orang.
\end{abstract}

Kata Kunci: Reputasi, Pendapatan Non-Halal, Zakat, Dewan Pengawas Syariah. 


\section{PENDAHULUAN}

Reputasi dimaknai sebagai nilai yang diberikan kepada individu, institusi atau bahkan negara atas pencapaian (Darsiya, Amin, and Junaidi 2019). Reputasi memiliki andil besar dalam menjalin kemitraan antara bank syariah dengan nasabah dan menjadi dasar penilaian dalam menentukan kelayakan perusahaan sebagai mitra kerjasama (Junusi 2012). Lebih dari dua dekade bank syariah hadir dalam industri perbankan di Indonesia. Kemurnian syariah akan dana yang dititipkan menjadi harapan bagi banyak umat Islam, salah satunya adalah memelihara agar dana tersebut tidak tercampur dengan dana non-halal dan diinvestasikan dalam transaksi yang halal pula (Maulidha and Bayinah 2014). Selain itu, kewajiban zakat pun telah dilaksanakan oleh sebagian dari bank syariah besar di Indonesia sebagai salah satu dari nilai bisnisnya, walaupun ditemukan bahwa zakat yang dikeluarkan masih rendah (Meilani, Andraeny, and Rahmayati 2016). Fungsi zakat dalam sudut pandang bank syariah tidak hanya sebagai bentuk pemenuhan kewajiban agama, melainkan sebagai cara bank syariah dalam menjaga citra perusahaannya, sehingga mampu menciptakan reputasi yang baik dari stakeholder (Sidik and Reskino 2016).

Untuk memastikan bahwa bank syariah telah menjalankan kegiatan usahanya sesuai dengan prinsip syariah, maka dalam struktur organisasinya bank syariah perlu menempatkan Dewan Pengawas Syariah sebagai fungsi pengawasan. Sebagai bentuk pengawasan bank syariah yang sesuai dengan prinsip muamalah dan Islam, maka dibentuklah Dewan Pengawas Syariah (DPS). Tanggung jawab DPS sebagai pemegang otoritas pengawasan terhadap kepatuhan syariah (sharia compliance) telah diatur dalam peraturan sehingga memiliki dasar hukum yang jelas (Nurhisam 2016). Prabowo and Jamal (2017) menjelaskan bahwa citra dan kredibilitas perbankan syariah di mata publik juga bergantung pada kepatuhan syariah, sehingga adanya pelanggaran yang diabaikan oleh DPS dapat mengurangi kepercayaan masyarakat terhadap perbankan syariah. Pada prinsipnya, pelanggaran atas prinsip syariah menyalahi kepercayaan masyarakat dan amanah yang diberikan oleh Allah Subhanahu wa Ta'alaa sebagai pemilik seluruh sumber daya yang dimiliki para stakeholders seperti yang termaktub dalam shari'ate enterprise theory (Mulawarman 2009, 115).

Penelitian yang mengkaji tentang reputasi perbankan syariah dengan zakat telah dilakukan oleh Sidik and Reskino (2016) yang membuktikan bahwa zakat memiliki pengaruh yang positif dan signifikan terhadap reputasi perusahaan. Selain itu, Darsiya et al. (2019) membuktikan bahwa zakat memiliki dampak positif tidak signifikan pada reputasi bank umum syariah. Junusi (2012) terkait implementasi syariah governance serta implikasinya terhadap reputasi dan kepercayaan bank syariah yang menunjukkan skor dengan kategori baik. Sementara itu, penelitian tentang hubungan DPS dengan reputasi dilakukan oleh Prabowo and Jamal (2017) yang membuktikan bahwa kepatuhan syariah yang diawasi oleh DPS akan meningkatkan citra dan kredibilitas perbankan syariah di mata publik yang berdampak kepada meningkatnya kepercayaan masyarakat terhadap perbankan syariah. Sebagaimana penelitian yang dilakukan oleh Purwanti (2016) berdasar pada Islamic Social Reporting bahwa jumlah DPS berpengaruh positif secara signifikan terhadap luasnya pengungkapan aspek produk/jasa dan aspek lingkungan. 
Sementara itu, Muchlis and Utomo (2018) melalui kajian kualitatif mendapati bahwa pendapatan non-halal dari giro yang berasal dari bank lain dapat mempengaruhi tingkat reputasi bank Muamalat dan menyebabkan turunnya kepercayaan nasabah dalam menabung. Walaupun telah banyak penelitian yang meneliti tentang reputasi bank syariah seperti yang dilakukan oleh Junusi (2012); Arifin and Wardani (2016); Muchlis and Utomo (2018), namun belum banyak yang menghubungkan antara reputasi dengan zakat serta dewan pengawas syariah. Terlebih lagi, peneliti memasukkan pendapatan non-halal sebagai variabel baru yang belum pernah diteliti sebelumnya pengaruhnya terhadap reputasi perbankan syariah. Berdasarkan fenomena dan keterbatasan penelitian di Indonesia, maka penelitian kali ini bertujuan untuk menganalisis hubungan pendapatan non-halal berpengaruh negatif terhadap reputasi perbankan syariah di Indonesia. Bagaimana pengaruh dan hubungan antara zakat dengan reputasi perbankan syariah di Indonesia? Apakah jumlah DPS berpengaruh terhadap reputasi pada bank syariah di Indonesia?

\section{TELAAH LITERATUR}

\section{Shari'ate Enterprise Theory}

Shariate enterprise theory menjelaskan akan pentingnya menjunjung tinggi tanggung jawab dalam penggunaan, cara dan tujuan dalam mengemban amanah yang diterima berdasarkan nilai keadilan, kebenaran dan kejujuran. Dalam Islam diwajibkan untuk memiliki sifat amanah yaitu dapat di percaya. Kepercayaan stakeholders sangat penting dalam menentukan reputasi dan keberlangsungan suatu bank (Muchlis and Utomo, 2018). Menurut teori ini, stakeholders meliputi direct participants dan indirect participants (Mulawarman 2009, 115). Direct participants, adalah pihak yang memberi kontribusi kepada perusahaan, keuangan maupun non keuangan (misalnya tenaga dan skill). Pihak pertama meliputi pemegang saham, karyawan, kreditor, pemerintah, pemasok, pelanggan dan lainnya. Indirect participants adalah pihak yang sama sekali tidak memberikan kontribusi kepada perusahaan baik keuangan maupun non keuangan, tetapi dengan statusnya yang demikian justru mereka mempunyai hak atas bagian kesejahteraan yang berhasil diciptakan perusahaan. Pihak kedua ini meliputi: masyarakat secara umum (khususnya mustahiq) dan lingkungan alam (dalam arti menjaga, memperbaiki dan melestarikan alam) (Mulawarman 2009, 116). Tujuan pokok dari keberadaan perbankan syariah adalah munculnya kesadaran masyarakat muslim yang ingin menjalankan seluruh aktivitas keuangannya berdasarkan Al-Quran dan Sunnah. Oleh karena itulah jaminan mengenai pemenuhan terhadap syariah (sharia compliance) dari seluruh aktivitas pengelolaan dana nasabah oleh bank syariah merupakan hal yang sangat penting dalam kegiatan usaha bank syariah (Junusi 2012). Penerapan prinsip shariate enterprise theory pada perbankan syariah akan membuat kinerja bank lebih sehat, dikarenakan manajemen akan mematuhi prinsip-prinsip yang telah ditetapkan. Semakin tinggi tingkat kepatuhan syariah akan memungkinkan bank untuk mendapatkan kategori sebagai bank sehat. Penerapan prinsip shariate enterprise theory bank umum syariah harus memberikan informasi yang akurat dan transparan, sehingga pemilik modal yakin akan kebenaran informasi laporan 
keuangan yang di terbitkan oleh pihak bank umum syariah. (Muchlis and Utomo 2018).

\section{Reputasi}

Reputasi perusahaan adalah suatu pandangan stakeholders pada perusahaan yang dinilai dari baik atau tidaknya hal-hal seperti keterbukaan, kualitas dan kinerja (Stuebs and Sun 2014). Reputasi yang kokoh (solid reputation) terbentuk melalui identitas organisasi yang khas, proyeksi citra-citra publik yang konsisten dan komunikasi persuasif yang positif pada segenap jenis konstituensi (Muchlis and Utomo 2018). Reputasi dapat menjadi aspek yang harus diperhatikan oleh bank. Salah satu alasan utama konsumen membuat keputusan menabung adalah reputasi bank (Widowati and Mustikawati 2018).

\section{Pendapatan Non-Halal}

Penerimaan non-halal adalah semua penerimaan dari kegiatan yang tidak sesuai dengan prinsip syariah antara lain penerimaan jasa giro atau bunga yang berasal dari bank umum konvensional. Penerimaan non-halal pada umumnya terjadi dalam kondisi darurat atau kondisi yang tidak diinginkan oleh entitas syariah karena secara prinsip dilarang (Ikatan Akuntan Indonesia 2019). Hartanto, Pramono, and Purnamasari (2019) menyatakan bahwa sumber dana non halal di Bank Umum Syariah dan Unit Usaha Syariah didominasi oleh pendapatan bunga bank dan jasa giro. Sedangkan penggunaan dana non halal didominasi oleh kegiatan sosial.

\section{Zakat}

Zakat adalah sebagian dari harta yang wajib dikeluarkan oleh wajib zakat (muzakki) untuk diserahkan kepada penerima zakat (mustahiq). Pembayaran zakat dilakukan apabila muzakki telah memenuhi nisab dan haul dengan sumber perolehan dana yang halal dan thoyib (BAZNAS Center of Strategic Studies 2018). Darsiya et al. (2019) dalam penelitiannya mengungkapkan bahwa pengungkapan zakat secara terus menerus dan konsisten akan selalu menumbuhkan kepercayaan publik terhadap bank.

\section{Dewan Pengawas Syariah (DPS)}

Menurut OJK tahun 2017 dijelaskan bahwa DPS paling sedikit mempunyai tugas dan wewenang untuk memberikan nasihat dan saran kepada Direksi, mengawasi aspek syariah kegiatan operasional yang wajib dimuat dalam anggaran dasar perusahaan. DPS terdiri atas 1 (satu) orang ahli syariah atau lebih yang diangkat oleh RUPS atas rekomendasi Dewan Syariah Nasional Majelis Ulama Indonesia dan dituangkan dalam akta notaris (Otoritas Jasa Keuangan 2017). Semua transaksi di perbankan syariah harus dipantau secara optimal oleh DPS yang merupakan lanjutan dari DSN untuk meluruskan kesalahan yang terjadi dalam operasional perbankan syariah (Prabowo and Jamal 2017). DPS melakukan pengawasan syariah dengan menguji kesesuaian praktik perbankan dengan kriteria dan acuan yang telah ditentukan oleh Bank Indonesia (Astuti 2015). 


\section{Hubungan Antara Pendapatan Non-Halal dan Reputasi Perbankan Syariah}

Transaksi pada perbankan Syariah tidak menerapkan sistem bunga atas kegiatan usahanya. Pemasukan pemasukan dana dan pengeluaran dana yang ada di Bank Syariah bersumber dari dana yang halal dan digunakan untuk kepentingan pembiayaan kepada masyarakat atau investasi syariah yang bebas dari unsur ketidakpastian (Gharar), investasi bunga (riba) dan perjudian (maisir) yang mencakup semua aspek kehidupan (way of life) (Maulidha and Bayinah 2014). Hartanto et al. (2019) menunjukkan bahwa sumber dana non-halal di industri perbankan didominasi oleh pendapatan bunga dari bank konvensional lain. Selanjutnya, Muchlis and Utomo (2018) menemukan bahwa sebagian nasabah di bank Muamalat belum mengetahui bahwa dana yang mereka titipkan pada bank Muamalat ada yang menghasilkan pendapatan non-halal. Pendapatan non-halal yang diperoleh oleh bank Muamalat tersebut dapat mempengaruhi kepercayaan para nasabah secara khusus, maupun stakeholders. Justru, adanya penurunan kepercayaan stakeholders, akan menjadi sinyal negatif bagi eksistensi bank syariah yang selama ini diyakini telah berjalan sesuai prinsip syariah. Sehingga, lambat laun akan dikhawatirkan akan mengikis reputasi perusahaan yang telah lama dibangun dan dipertahankan oleh bank syariah. Dari penjelasan tersebut, peneliti merumuskan hipotesis sebagai berikut:

H1: Pendapatan non-halal berpengaruh negatif terhadap reputasi perbankan syariah.

\section{Hubungan Antara Zakat dan Reputasi Perbankan Syariah}

Harta yang dikelola di perusahaan yang memiliki objek berkembang, baik secara riil maupun estimasi tunduk kepada harta wajib zakat (BAZNAS Center of Strategic Studies 2018). Zakat dihitung sebagai pengurang laba bersih untuk menghasilkan jumlah laba bersih setelah zakat. Pos zakat hasil usaha disajikan sebagai pos terpisah dari pendapatan dan beban (Amirah and Raharjo 2014). Darsiya et al. (2019) membuktikan bahwa zakat memiliki dampak positif tidak signifikan pada reputasi bank umum syariah. Sebaliknya, Amirah and Raharjo (2014) menjelaskan bahwa zakat berpengaruh signifikan terhadap kinerja keuangan perbankan syariah. Begitu juga dengan Sidik and Reskino (2016) membuktikan bahwa zakat memiliki pengaruh yang positif dan signifikan terhadap reputasi perusahaan. Dari penjelasan tersebut, peneliti mengemukakan hipotesis sebagai berikut:

H2: Zakat berpengaruh positif terhadap reputasi perbankan syariah.

\section{Hubungan Antara Dewan Pengawas Syariah (DPS) dan Reputasi Perbankan Syariah}

DPS memiliki peranan yang amat penting dalam kontrak syariah yaitu membuat pedoman persetujuan produk dan operasional serta laporan rutin setiap tahun. Adapun dalam operasionalisasinya pengawasan terhadap bank syariah dilakukan untuk memastikan bahwa dalam kegiatan operasionalnya bank syariah telah berjalan sesuai dengan ketentuan Syariah (Prabowo and Jamal 2017). Proses pengawalan kepatuhan syariah oleh DPS harus sesuai dengan aturan yang telah ditetapkan oleh Accounting And Auditing Organization for Islamic Financial Institutions (AAOIFI) dan Islamic Financial Services Board (IFSB) (Nurhisam 2016). Selain itu, fungsi dan peran DPS dalam perbankan syariah sangat 
berhubungan erat dengan manajemen risiko perbankan syariah, yaitu risiko reputasi, yang memungkinkan adanya dampak pada risiko lainnya, seperti risiko likuiditas (Astuti 2015). Oleh karena itu, risiko reputasi pada bank syariah sebagai bagian yang dapat merobohkan image bank syariah wajib diantisipasi agar tidak berdampak terhadap industri perbankan syariah secara keseluruhan (Junusi 2012).

Terkait hal tersebut, DPS dituntut aktif dalam melakukan supervisi, mengumpulkan data, menganalisis dan melakukan koreksi terhadap berbagai temuan ketidakpatuhan syariah pada sebuah bank syariah (Purwanti 2016). Sehingga, diharapkan semakin banyak jumlah DPS pada bank syariah akan membuat bank syariah memiliki tingkat kepatuhan syariah yang tinggi sehingga dapat meningkatkan reputasi perbankan syariah di mata para stakeholders. Selain itu, Efektifitas DPS akan lebih tampak bila sering melakukan pembahasan/diskusi atas masalah yang dikhawatirkan akan melanggar prinsip syariah dalam menjalankan operasi perbankan syariah (Purwanti 2016). Berdasarkan penjelasan tersebut, maka hipotesis yang diajukan sebagai berikut:

H3: Jumlah DPS berpengaruh positif terhadap reputasi perbankan syariah.

Memperhatikan pengaruh pendapatan non-halal, zakat, dan DPS terhadap reputasi perbankan syariah, maka dibentuk kerangka teoritis, seperti terlihat pada Gambar 1.

\section{Gambar 1 Kerangka Teoritis}

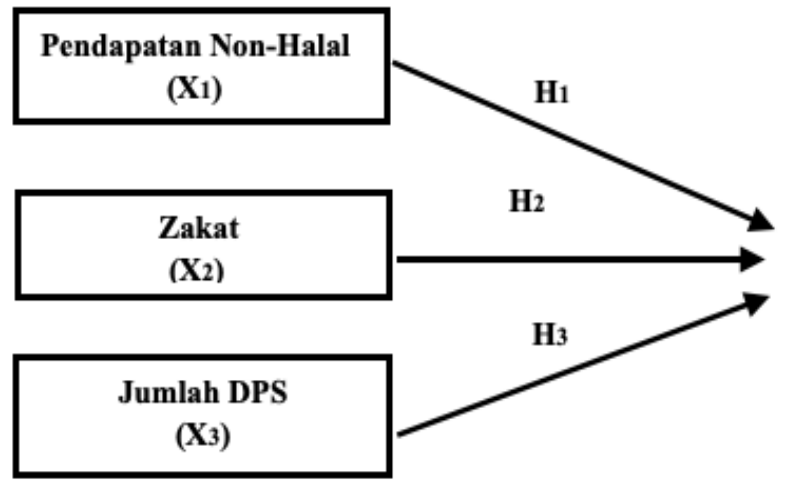

\section{METODE PENELITIAN}

Metode analisis data menggunakan analisis regresi linear berganda (Ghozali 2013, 96). Pengolahan data dilakukan dengan bantuan software SPSS 23. Desain penelitian ini adalah kuantitatif dengan pendekatan asosiatif. Tujuannya adalah untuk menguji hipotesis mengenai hubungan keseimbangan jangka panjang satu variabel dengan variabel lainnya. Variabel terikat (Y) adalah reputasi perbankan syariah, sedangkan variabel bebas adalah pendapatan nonhalal $\left(\mathrm{X}_{1}\right)$, zakat $\left(\mathrm{X}_{2}\right)$, jumlah DPS $\left(\mathrm{X}_{3}\right)$, dimana pengukuran variabel dapat dilihat pada Tabel 3. Perbedaan dengan penelitian sebelumnya, dalam penelitian ini, tidak hanya konstruktif tetapi juga menguji hubungan kausal atau sebab akibat (eksperimen). 
Tabel 1 Definisi Pengukuran Variabel

\begin{tabular}{|c|c|c|c|}
\hline No & Variabel & Definisi Operasional & Pengukuran \\
\hline 1 & Reputasi & $\begin{array}{l}\text { Reputasi Perbankan Syariah } \\
\text { yang diukur dengan } \\
\text { membandingkan persentase } \\
\text { Dana Pihak Ketiga (DPK) } \\
\text { yang dikelola oleh bank } \\
\text { dengan Total DPK Gabungan } \\
\text { yang dikelola oleh seluruh } \\
\text { BUS dan UUS }\end{array}$ & $\frac{\text { Dana Pihak Ketiga (DPK) }}{\text { Total DPK Gabungan }}$ \\
\hline 2 & $\begin{array}{l}\text { Pendapatan non- } \\
\text { halal }\end{array}$ & $\begin{array}{l}\text { Pendapatan non-halal diukur } \\
\text { berdasarkan total pendapatan } \\
\text { non-halal yang diterima oleh } \\
\text { perusahaan pada tahun tersebut } \\
\text { dan dapat dilihat pada laporan } \\
\text { sumber dan penggunaan dana } \\
\text { kebajikan }\end{array}$ & $\begin{array}{l}\Sigma \text { Pendapatan non-halal } \\
\text { tahun ke } \mathrm{n}\end{array}$ \\
\hline 3 & Zakat & $\begin{array}{l}\text { Zakat diukur berdasarkan } \\
\text { jumlah zakat yang disalurkan } \\
\text { oleh perusahaan pada tahun } \\
\text { tersebut dan dapat dilihat pada } \\
\text { laporan sumber dan } \\
\text { penyaluran dana zakat yang } \\
\text { terdapat pada laporan } \\
\text { keuangan perusahaan }\end{array}$ & $\begin{array}{l}\Sigma \text { Zakat yang disalurkan } \\
\text { perusahaan tahun ke } n\end{array}$ \\
\hline 4 & Jumlah DPS & $\begin{array}{l}\text { Jumlah DPS diukur } \\
\text { berdasarkan jumlah DPS yang } \\
\text { dimiliki oleh bank umum } \\
\text { syariah }\end{array}$ & $\Sigma$ DPS tahun ke $\mathrm{n}$ \\
\hline
\end{tabular}

Sumber: data olahan

\section{Populasi dan Sampel}

Populasi terdiri dari 12 perbankan syariah, teknik sampel yang digunakan adalah teknik purposive sampling dengan dukungan data sekunder yang berasal dari laporan keuangan yang dipublikasi pada website Otoritas Jasa Keuangan yaitu www.ojk.go.id dan website masing-masing perbankan syariah selama periode 2014 hingga 2018. Sampel akhir didapat sebanyak 7 perusahaan dimana 5 perusahaan tidak memenuhi kriteria, sehingga diperoleh 35 data hasil observasi selama 5 tahun.

\section{HASIL DAN PEMBAHASAN PENELITIAN}

\section{Statistik Deskriptif}

Hasil statistik deskriptif pada Tabel 2 menunjukkan bahwa nilai minimum variabel reputasi sebesar 0,00 dengan nilai maksimum sebesar 0,27. Sementara nilai mean yaitu 0,0891 dan standar deviasi sebesar 0,08936. Variabel pendapatan non-halal memiliki nilai minimum sebesar 14 dengan nilai maksimum sebesar 21 . Di mana nilai mean yaitu sebesar 18,37 dan standar deviasi sebesar 2,377. Selanjutnya, nilai minimum variabel zakat menunjukkan nilai sebesar 17 dan nilai maksimum sebesar 24, nilai mean sebesar 21,31 dan standar deviasi yaitu 2,506. 
Variabel jumlah DPS dapat dilihat bahwa nilai minimumnya sebesar 2 dengan nilai maksimum sebesar 3. Nilai mean jumlah DPS sebesar 2,29 dan standar deviasinya sebesar 0,458 .

Tabel 2 Hasil Statistik Deskriptif

\begin{tabular}{lccccc}
\hline & $\boldsymbol{N}$ & Minimum & Maximum & Mean & Std. Deviation \\
\hline Reputasi & 35 & 0,00 & 0,27 & 0,0891 & 0,08936 \\
Pendapatan non-halal & 35 & 14 & 21 & 18,37 & 2,377 \\
Zakat & 35 & 17 & 24 & 21,31 & 2,506 \\
Jumlah DPS & 35 & 2 & 3 & 2,29 & 0,458 \\
Valid N (listwise) & $\mathbf{3 5}$ & & & & \\
\hline Suli
\end{tabular}

Sumber: data olahan

\section{Uji Kelayakan Model}

Tabel 3 Hasil Uji Kelayakan Model

\begin{tabular}{cc}
\hline $\boldsymbol{F}$ & Sig. \\
\hline 58,494 & $0,000^{\mathrm{b}}$ \\
\hline Sumber: data olahan &
\end{tabular}

Berdasarkan Tabel 3 bahwa hasil uji kelayakan model menunjukkan nilai sig. sebesar 0,000. Sehingga dapat dikatakan bahwa semua variabel independen layak untuk menjelaskan variabel dependen yang dianalisis.

\section{Analisis Regresi Linear Berganda}

Tabel 4 Hasil Uji Regresi Berganda

\begin{tabular}{lcc}
\hline \multicolumn{1}{c}{ Model } & $\begin{array}{c}\text { Unstandardized } \\
\text { Coefficients }\end{array}$ & Sig. \\
\hline Beputasi & $-0,472$ & 0,000 \\
Pendapatan non-halal & $-0,005$ & 0,180 \\
Zakat & 0,016 & 0,000 \\
Jumlah DPS & 0,138 & 0,000 \\
\hline Sumber: data olahan & &
\end{tabular}

Berdasarkan Tabel 4, hasil sig. variabel pendapatan non-halal menunjukkan nilai 0,180 >0,05 dengan arah negatif. Artinya, pendapatan nonhalal tidak berpengaruh terhadap reputasi, sehingga dapat dikatakan bahwa hipotesis H1 ditolak. Hasil sig. variabel zakat menunjukkan nilai 0,000 $<0,05$ dengan arah positif. Artinya, zakat berpengaruh terhadap reputasi, sehingga dapat dikatakan bahwa hipotesis $\mathbf{H 2}$ diterima. Hasil sig. variabel jumlah DPS menunjukkan nilai $0,000<0,05$ dengan arah positif. Artinya, jumlah DPS berpengaruh terhadap reputasi. Sehingga dapat dikatakan bahwa hipotesis $\mathbf{H 3}$ diterima.

\section{Koefisien Determinasi $\left(R^{2}\right)$}

Tabel 5 Hasil Koefisien Determinasi

\begin{tabular}{ccc}
\hline $\boldsymbol{R}$ & $\boldsymbol{R}$ Square & Adjusted $\boldsymbol{R}$ Square \\
\hline $0,941^{\mathrm{a}}$ & 0,886 & 0,871 \\
\hline \multicolumn{2}{l}{ Sumber: data olahan }
\end{tabular}


Berdasarkan Tabel 5, hasil koefisien determinasi menunjukkan nilai adjusted $R$ square sebesar 0,871. Artinya, bahwa variabel Independen yang digunakan dalam penelitian ini mampu menjelaskan variabel dependen sebesar $87,1 \%$. Sementara $12,9 \%$ sisanya dijelaskan oleh faktor lain yang tidak dimasukkan dalam penelitian ini.

\section{Pengaruh Pendapatan Non-Halal Terhadap Reputasi Perbankan Syariah}

Hasil penelitian menunjukkan bahwa pendapatan non-halal tidak berpengaruh terhadap reputasi perbankan syariah. Namun, yang menarik adalah hubungan kedua variabel menunjukkan arah negatif. Artinya, semakin tinggi pendapatan non-halal maka akan menurunkan reputasi perbankan syariah. Bagi sebagian besar muslim, memiliki sistem keuangan yang patuh pada prinsip dan tujuan syariah Islam merupakan cita-cita luhur yang mereka harapkan. Namun, praktik beberapa lembaga keuangan Islam dalam kasus-kasus tertentu, menimbulkan berbagai keraguan akan kredibilitas dan integritas dan tidak jarang masyarakat mulai merasa was-was jika berurusan dengan bank, baik bank syariah maupun lembaga keuangan lainnya (Almahy, Al-Sahn, and Beloucif 2014). Sehingga dalam hal ini perlu adanya upaya yang nyata bahwa semua aktivitas perusahaan harus dikeluarkan pada objek dan tujuan yang jelas dan bebas dari unsur haram (Maulidha and Bayinah 2014).

Shariate enterprise theory menjelaskan bahwa dalam sumber daya yang ada dalam perusahaan melekat suatu tanggung jawab dalam penggunaan. Tanggung jawab ini sebagai bentuk dalam menjalankan amanah yang sudah ditetapkan Allah. Shamma (2012) menegaskan bahwa reputasi menjadi sangat penting saat ini, karena perusahaan dihadapkan tingginya kesadaran masyarakat akan berbagai tindakan dilakukan oleh perusahaan, sehingga tuntutan akan transparansi semakin meningkat. Terlebih lagi, adanya ekspektasi yang tinggi dari para stakeholders terhadap perusahaan. Sehingga dapat dikatakan bahwa menjaga reputasi melalui pemenuhan amanah (tanggung jawab) dan kesadaran akan banyaknya pihak yang berkepentingan terhadap perusahaan harusnya mendorong bank syariah dalam menjalankan bisnisnya dengan penuh kepatuhan terhadap prinsip syariah. Adanya pendapatan non-halal dalam catatan laporan keuangan perusahaan menunjukkan bahwa bank syariah khususnya di Indonesia belum sepenuhnya taat pada ketentuan syariah. Fakta ini juga diperkuat oleh penelitian Muchlis and Utomo (2018) yang menemukan bahwa sebagian nasabah belum mengetahui bahwa dana yang mereka titipkan pada salah satu bank syariah ada yang menghasilkan pendapatan non-halal.

\section{Pengaruh Zakat Terhadap Reputasi Perbankan Syariah}

Hasil penelitian menunjukkan bahwa zakat berpengaruh terhadap reputasi perbankan syariah. Hasil penelitian ini sejalan dengan penelitian Amirah and Raharjo (2014); Sidik and Reskino (2016) yang menyatakan bahwa zakat memiliki pengaruh yang positif dan signifikan terhadap reputasi dan kinerja perusahaan. Namun, kontradiktif dengan hasil yang ditemukan oleh Darsiya et al. (2019) yang membuktikan bahwa zakat tidak berpengaruh terhadap reputasi bank umum syariah. Terkait dengan penelitian tentang zakat, Rusydiana and Firmansyah (2017) menemukan fakta bahwa bank umum syariah dalam mengeluarkan zakat sangat dipengaruhi oleh seberapa besar ukuran perusahaan 
dalam hal ini aset yang dimiliki. Ini kaitannya dengan keberadaan bank umum syariah di Indonesia mayoritas masih baru sehingga operasional bank masih dalam tahap meningkatkan pangsa pasar sehingga segala bentuk pengeluaran termasuk zakat masih banyak pertimbangan dan mungkin masih dianggap beban yang nilainya signifikan, padahal UU. No. 17/2000 menyebutkan bahwa pengeluaran zakat bukanlah pengeluaran beban perusahaan yang akan memberatkan perusahaan akan tetapi hanya menjadi pengurang dalam penghasilan kena pajak. Selain itu Meilani et al. (2016) menjelaskan bahwa zakat yang dikeluarkan oleh bank syariah di Indonesia masih rendah dan perbedaan kesejahteraan direktur dengan karyawan bank syariah masih besar.

Dalam konteks shariate enterprise theory dikenal istilah indirect participants yaitu pihak yang sama sekali tidak memberikan kontribusi kepada perusahaan baik keuangan maupun non keuangan, tetapi dengan statusnya yang demikian justru mereka mempunyai hak atas bagian kesejahteraan yang berhasil diciptakan perusahaan. Pihak kedua ini meliputi masyarakat secara umum termasuk mustahiq/penerima zakat (Mulawarman 2009, 116). Mengeluarkan zakat oleh bank syariah, selain merupakan bentuk ketaatan terhadap prinsip syariah, juga merupakan suatu media yang tepat dalam membentuk reputasi yang kokoh bagi bank syariah. Iwu-Egwuonwu (2011) menegaskan bahwa reputasi yang kokoh merupakan fondasi yang kuat dalam menaklukan persaingan bisnis, memperluas pangsa pasar, kinerja keuangan serta eksistensi bank syariah di masa yang akan datang.

\section{Pengaruh Jumlah DPS Terhadap Reputasi Perbankan Syariah}

Hasil penelitian menunjukkan bahwa jumlah DPS berpengaruh terhadap reputasi perbankan syariah. Hasil penelitian ini sejalan dengan penelitian Purwanti (2016). El-Halaby and Hussainey (2016) menemukan bahwa mekanisme tata kelola perusahaan yang terkait dengan DPS berpengaruh terhadap pengungkapan kepatuhan standar AAOIFI oleh bank syariah. Dijelaskan pula bahwa DPS memiliki peran yang signifikan dalam menyusun laporan tentang tingkat kepatuhan terhadap syariah. Reputasi perusahaan dimaknai sebagai hasil logis dari kualitas tata kelola perusahaan yang dioperasikan dalam suatu organisasi (IwuEgwuonwu 2011). Alam, Miah, Siddiquii, and Hossain (2020) menyatakan bahwa jika anggota DPS percaya diri, maka akan sulit bagi manajemen untuk memengaruhi. Namun, dalam banyak kasus ditemukan bahwa adanya intervensi manajemen mengakibatkan tata kelola yang bias. Nomran and Haron (2020) mengungkapkan akan pentingnya ukuran DPS dalam meningkatkan kinerja bank syariah. Jumlah DPS yang ideal adalah antara 3 sampai dengan 6 orang. Meskipun ukuran DPS memainkan peran penting dalam mempengaruhi kinerja bank syariah. Namun, belum ada bukti empiris berapa jumlah optimal DPS yang paling tepat. Nurhisam (2016) menjelaskan bahwa DPS sebagai pemegang otoritas pengawasan terhadap kepatuhan syariah (sharia compliance) memiliki tanggung jawab yang diatur melalui ketentuan hukum yang tegas. Walaupun, pada faktanya Prabowo and Jamal (2017) menemukan bahwa masih terdapat pelanggaran kepatuhan syariah yang dibiarkan oleh DPS yang tentunya akan merusak citra dan kredibilitas perbankan syariah di mata publik. Astuti (2015); Alama, Rahman, Thakur, Bashir, and Hosen (2020) menyatakan bahwa pengawasan syariah selama ini dilakukan oleh DPS belum memiliki pedoman 
yang standar bagi semua anggota DPS, tata cara pengawasan dan pelaporan sepenuhnya diserahkan kepada anggota DPS.

\section{KESIMPULAN}

Pendapatan non-halal tidak berpengaruh terhadap reputasi perbankan syariah. Zakat berpengaruh terhadap reputasi perbankan syariah. Zakat di Indonesia sangat dipengaruhi oleh seberapa besar ukuran perusahaan dalam hal ini aset yang dimiliki. Zakat yang dikeluarkan oleh bank syariah di Indonesia masih rendah dan perbedaan kesejahteraan direktur dengan karyawan bank syariah masih besar. Jumlah DPS berpengaruh terhadap reputasi perbankan syariah. DPS memiliki peran yang signifikan dalam menyusun laporan tentang tingkat kepatuhan terhadap syariah.

Jumlah bank umum syariah ataupun perusahaan yang berbasis syariah yang laporan keuangannya dapat diakses melalui website perusahaan sangat terbatas, terkecuali bank umum syariah nasional khususnya yang terdaftar di Bursa Efek Indonesia. Hal ini berefek pada jumlah sampel yang diteliti cukup kecil. Lingkup penelitian hanya terbatas pada satu negara yaitu di Indonesia.

Adanya pendapatan non-halal dalam catatan laporan keuangan perusahaan menunjukkan bahwa bank syariah khususnya di Indonesia belum sepenuhnya taat pada ketentuan syariah, hal ini menunjukkan bahwa peran DPS masih belum optimal, sehingga diharapkan bagi perusahaan untuk mempertimbangkan komposisi DPS yag ideal dalam perusahaan. Jumlah DPS yang ideal adalah antara 3 sampai dengan 6 orang. Dengan demikian, dapat membantu pengawan perusahaan secara lebih efektif. Bagi peneliti selanjutnya yang ingin meneliti variabel yang sama, disarankan untuk meneliti tentang perbandingan antara kasus di Indonesia dengan negara-negara Islam lainnya seperti Malaysia, Arab, Bangladesh, dana negara lain yang menjalankan sistem perbankan syariah.

\section{DAFTAR PUSTAKA}

Alam, Md. Kausar, Muhammad Shahin Miah, Md. Naim Siddiquii, Mohammad Imtiaz Hossain. 2020. "The influences of board of directors and management in Shariah governance guidelines of the Islamic banks in Bangladesh." Journal of Islamic Accounting and Business Research 11 (9): 1633-1647. https://doi.org/10.1108/JIABR-08-2019-0155.

Alama, Kausar, Suhaimi Ab. Rahman, Oli Ahad Thakur, Abdul Bashir, and Sharif Hosen. 2020. "The Reasons Behind the Absence of a Comprehensive Shariah Governance Framework of Islamic Banks in Bangladesh." International Journal of Economics \& Business Administration (IJEBA) 8 (1): 134-145. https://www.um.edu.mt/library/oar/handle/123456789/53886.

Almahy, Jaafar, Farid Al-Sahn, and Ahmed Beloucif. 2014. "The Corporate Reputation of Islamic Banks: A Measurement Scale". International Journal of Marketing Studies 6 (6): 91-103. https://doi.org/10.5539/ijms.v6n6p91.

Amirah, Amirah, and Teguh Budi Raharjo. 2014. "Pengaruh Alokasi Dana Zakat Terhadap Kinerja Keuangan Perbankan Syariah.” PERMANA: Jurnal 
Perpajakan, Manajemen dan Akuntansi 5 (2): 73-81. http://ejournal.upstegal.ac.id/index.php/per/article/view/369.

Arifin, Johan, and Eke Ayu Wardani. 2016. "Islamic corporate social responsibility disclosure, reputasi, dan kinerja keuangan: Studi pada bank syariah di Indonesia". Jurnal Akuntansi Dan Auditing Indonesia (JAAI) 20 (1): 38-46. http://dx.doi.org/10.20885/jaai.vol20.iss1.art4.

Astuti, Rahma Yudi. 2015. "Analisa Kinerja Dewan Pengawas Syariah di Bank Syariah". $\quad A l \quad$ Tijarah 1 (2): http://dx.doi.org/10.21111/tijarah.v1i2.955.

BAZNAS Center of Strategic Studies. 2018. Fiqih Zakat Perusahaan. Jakarta: Pusat Kajian Strategis Badan Amil Zakat Nasional. https://www.puskasbaznas.com/publication/books/762-fiqih-zakatperusah.

Darsiya, Nuril Alfi, Moh. Amin, and Junaidi Junaidi. 2019. "Dampak Zakat dan Tanggung Jawab Sosial (CSR) pada Reputasi dan Hasil Kerja Bank Umum Syariah.” Jurnal Ilmiah Riset Akuntansi 8 (01): 71-81. http://riset.unisma.ac.id/index.php/jra/article/view/2827.

El-Halaby, Sherif, and Khaled Hussainey. 2016. "Determinants of Compliance with AAOIFI Standards by Islamic Banks." International Journal of Islamic and Middle Eastern Finance and Management 9 (1): 143-168. https://doi.org/10.1108/IMEFM-06-2015-0074.

Ghozali. Imam. 2013. Aplikasi Analisis Multivariate dengan Program SPSS Cetakan IV. Semarang: Badan Penerbit Universitas Diponegoro.

Hartanto, Rudy, Irena Paramita Pramono, and Pupung Purnamasari. 2019. "Analisis Pendapatan Non Halal Perbankan Syariah Di Indonesia : Sumber Dan Penggunaannya". Falah: Jurnal Ekonomi Syariah 4 (2): 159-171. https://doi.org/10.22219/jes.v4i2.10087.

Ikatan Akuntan Indonesia. (2019). PSAK 101: Penyajian Laporan Keuangan Syariah. http://iaiglobal.or.id.

Iwu-Egwuonwu, Ronald Chibuike. 2011. "Corporate Reputation \& Firm Performance: Empirical Literature Evidence." International Journal of Business and Management 6 (4): 197-206. https://doi.org/10.5539/ijbm.v6n4p197.

Junusi, Rahman El. 2012. "Implementasi Syariah Governance serta Implikasinya terhadap Reputasi dan Kepercayaan Bank Syariah". Al-Tahrir: Jurnal $\begin{array}{llll}\text { Pemikiran } & \text { Islam } & 12 & \text { (1): }\end{array}$ https://jurnal.iainponorogo.ac.id/index.php/tahrir/article/view/48.

Maulidha, E., and Bayinah, A.N. 2014. "Kerangka Pengungkapan Transaksi NonHalal di Bank Syariah”. Seminar Nasional Akuntansi Syariah (SNAS) 2014.

Meilani, Sayekti Endah Retno, Dita Andraeny, and Anim Rahmayati. 2016. "Analisis Kinerja Perbankan Syariah di Indonesia dengan Menggunakan Pendekatan Islamicity Indices". Seminar Nasional dan The 3rd Call for Syariah Paper, Universitas Muhammadiyah Surakarta.

Muchlis, Saiful, and Husain Soleh Utomo. 2018. "Kajian Pendapatan Non Halal dan Dampak Penggunaannya terhadap reputasi dan Kepercayaan Nasabah Perbankan Syariah (Study Empiris Pada Bank Muamalat)." JRAK: Jurnal Riset Akuntansi \& Komputerisasi Akuntansi 9 (1): 75-101. 
https://doi.org/10.33558/jrak.v9i1.1363.

Mulawarman, Aji Dedi. 2009. Akuntansi Syariah: Teori, Konsep dan Laporan Keuangan. Jakarta: Penerbit e-publishing.

Nomran, Naji Mansour, and Razali Haron. 2020. "Shari'ah supervisory board's size impact on performance in the Islamic banking industry: An empirical investigation of the optimal board size across jurisdictions." Journal of Islamic Accounting and Business Research 11 (1): 110-129. https://doi.org/10.1108/JIABR-05-2017-0070.

Nurhisam, Luqman. 2016. "Kepatuhan Syariah (Sharia Compliance) dalam Industri Keuangan Syariah.” Jurnal Hukum IUS QUIA IUSTUM 23 (1): 77-96. https://doi.org/10.20885/iustum.vol23.iss1.art5.

Otoritas Jasa Keuangan. 2017. Peraturan OJK Nomor 3/OJK.05/2017 Tentang Tata Kelola Perusahaan yang Baik Bagi Lembaga Penjamin. https://www.ojk.go.id/id/kanal/iknb/regulasi/lembaga-jasa-keuangankhusus/peraturan-ojk/Pages/POJK-Nomor-3-POJK.05-2017.aspx.

Prabowo, Bagya Agung, and Jasri Bin Jamal. 2017. "Peranan Dewan Pengawas Syariah terhadap Praktik Kepatuhan Syariah dalam Perbankan Syariah di Indonesia." Jurnal Hukum Ius Quia Iustum 24 (1): 113-129. https://doi.org/10.20885/iustum.vol24.iss1.art6.

Purwanti. Ari. 2016. "Dewan Pengawas Syariah dan Pengungkapan Aspek Lingkungan, Produk dan Jasa pada Bank Syariah." Jurnal Akuntansi dan Keuangan Islam 4 (2): 169-182. https://doi.org/10.35836/jakis.v4i2.25.

Rusydiana, Aam Slamet, and Irman Firmansyah. 2017. "Prioritizing Zakat Core Principles Criteria." Esensi: Jurnal Bisnis Dan Manajemen 7 (2): 277-302. https://doi.org/10.15408/ess.v7i2.5275.

Shamma, Hamed M. 2012. "Toward a Comprehensive Understanding of Corporate Reputation: Concept, Measurement and Implications." International Journal of Business and Management 7 (16): 151-169. https://doi.org/10.5539/ijbm.v7n16p151.

Sidik, Ichwan, and Reskino Reskino. 2016. "Pengaruh Zakat dan ICSR terhadap Reputasi dan Kinerja." Simposium Nasional Akuntansi XIX, Lampung, 2016.

http://lib.ibs.ac.id/materi/Prosiding/SNA\%20XIX\%20(19)\%20Lampung\% 202016/makalah/084.pdf.

Stuebs, Martin T., and Li Sun. 2011. "Corporate Social Responsibility and Firm Reputation." S\&P Global Market Intelligence Research Paper Series. https://dx.doi.org/10.2139/ssrn.1863343.

Widowati, Ayun Sekar, and RR. Indah Mustikawati. 2018. "Pengaruh Pengetahuan Produk Tabungan, Reputasi Bank, Dan Persepsi Nasabah Mengenai Suku Bunga Simpanan Terhadap Keputusan Menabung Nasabah." NOMINAL: Barometer Riset Akuntansi dan Manajemen 7 (2): 141-156. https://doi.org/10.21831/nominal.v7i2.21643. 